\title{
ÚJ ANYAGOK ÉS IRÁNYZATOK A TELJESÍTMÉNYELEKTRONIKÁBAN
}

\section{NEW MATERIALS AND TRENDS IN POWER ELECTRONICS}

\author{
Kelemen András \\ Sapientia EMTE, Marosvásárhelyi Kar, Villamosmérnöki Tanszék, 547367, Romá- \\ nia, Koronka, 1C; Telefon: +40-265-206210,kandras@ms.sapientia.ro
}

\begin{abstract}
The paper presents some key features of the wide-bandgap power semiconductor switches, that are expected to bring a new era in the design of power electronic converters. The challenges faced by the semiconductor technology involved are briefly discussed, and the increasing role in power applications of the $\mathrm{SiC}$ based devices is explained. Comparison of a Si-MOSFET and a SiC-MOSFET half-bridge module is made from the point of view of switching and conduction losses and heat management. The results clearly prove the benefits of the wide-bandgap switching devices, and we can expect that their application in high power converters will be one of the most significant future trends in power electronics.
\end{abstract}

Keywords: power electronics, converter, wide-bandgap semiconductor, SiC technology

\section{Összefoglalás}

A dolgozat a széles tiltott sávú, nagyteljesítményű félvezető kapcsolóeszközök olyan előnyeit tárgyalja, amelyek révén az áramirányítók tervezésében gyökeres szemléletmód váltás várható. A térhódításukhoz vezető technológiai eredmények rövid ismertetése során rámutatunk arra, hogy napjainkban miért éppen a SiC eszközök terjednek leginkább a nagyteljesítményű alkalmazásokban. A dolgozatban egy Si és egy SiC félhíd típusú teljesítmény modul összehasonlítására kerül sor a kapcsolási és vezetési veszteségek, illetve a hütési feltételek szempontjából. Az eredmények igazolják azt a várakozást, hogy a széles tiltott sávú félvezetők alkalmazása lesz a közeljövő egyik legmeghatározóbb irányzata a teljesítményelektronikában.

Kulcsszavak: teljesitményelektronika, áramirányitó, széles tiltott sávú félvezetö, SiC technológia

\section{A széles tiltott sávú félvezetők teljesítményelektronikai al- kalmazhatósága}

Az áramirányítók számos felhasználási területén a széles tiltott sávú kapcsolóeszközök bevezetése igen jelentős súly- és térfogatcsökkentést, hatásfoknövelést eredményez. Az anyagtudományi kutatások már hosszú ideje készítik elő ezt a lépést, de a megbízható, ipari alkalmazások számára hozzáférhető, széles tiltott sávú nagyteljesítményü kapcsolóeszközök megjelenése nagyon újszerü, és napjainkban nagyon látványos eredményekkel szolgál. Olyan intenzíven fejlődő ágazatok számára teremt ez kedvező konjunktúrát, mint az elektromos autók, és ezek töltőállomásainak fejlesztése, gyártása, illetve a megújuló energiaforrások hálózati csatlakoztatása, a leg- 
több energiakonverziós folyamatban jelentős hatásfoknövelést helyezve kilátásba.

A széles tiltott sávú félvezető kapcsolóeszközök elterjedését nagymértékben meghatározza ezek gyakorlati alkalmazhatósága, illetve a gyártási technológia megbízhatósága és költsége. A SiC diódák már évek óta jelen vannak a piacon, és az áramirányítók sok területen hasznosítják ezek nagy kapcsolási sebességét és ,zero recovery” tulajdonságát. A vezérelt kapcsolók gyakorlati alkalmazhatósága szempontjából az ú.n „normál nyitott” eszközök a kedvezőek, hiszen az áramirányítók tervezése és müködtetése sokkal kényelmesebb és biztonságosabb olyan eszközökkel, amelyek nincsenek vezetésben amikor a vezérlő áramkörök nem aktívak. A vezérelt kapcsolóeszközök közül elöször olyan „normál zárt” struktúrákat sikerült megvalósítani, mint pl. a SIT (Static Induction Transistor) [5], [6], de ezek teljesítményelektronikai alkalmazása nehézkes. A SiC MOSFET kapcsolók megjelenése viszont nagy lendületet adott az áramirányítók fejlődésének, mert változatlan topológia mellett jócskán javítják ezek hatásfokát, csökkentik méretét, súlyát, illetve megoldhatóvá tesznek a Si eszközökkel megoldhatatlan feladatokat.

\subsection{A félvezető anyagok teljesítmény- elektronikai szempontból megha- tározó tulajdonságai}

A széles tiltott sávú félvezető eszközöket a Si esetében megszokottnál nagyobb megengedett működési hőmérséklet, nagyobb letörési feszültség és kisebb vezetési és kapcsolási veszteségek jellemzik. Ezen tulajdonságok egyidejű optimizálása lehetetlen, mert egymásnak ellentmondó feltételeket támasztanak. Az anyagtulajdonságokat, illetve a különböző minőségi mutatók teljesítésének mértékét az 1. ábrán látható radardiagramok formájában szokás összefoglalni [1].

A széles tiltott sávú anyagok kecsegtető fizikai tulajdonságainak gyakorlati kihasz- nálása jelentős ösztönző erőt képvisel, a gyártási technológia fejlesztésére komoly előfeszítéseket tesznek, és ez a félvezető technológia számos területének lendületet ad.

Ugyanakkor felmerül a kérdés, hogy a kapcsolóeszközök paramétereinek a javulása milyen mértékben jelentkezik az áramirányítók különböző jellemzőinek a javulásában?

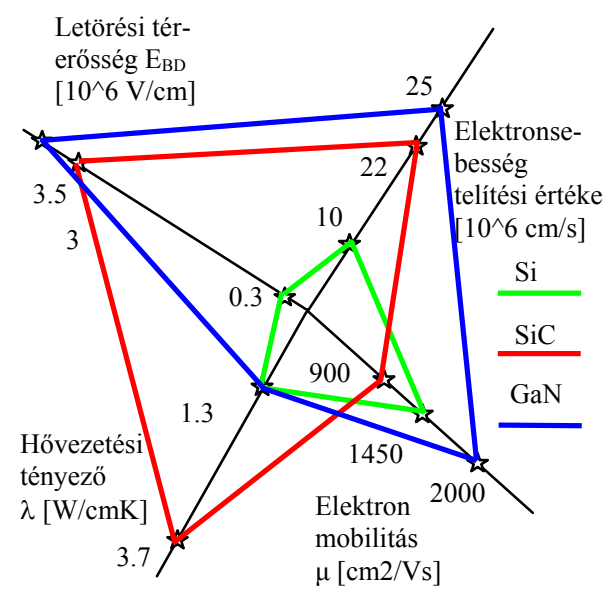

1. ábra. A Si, SiC-4H és a GaN félvezetö eszközök alkalmazási területeit nagymértékben befolyásoló fizikai tulajdonságok radardiagramja

\subsection{A technológiai háttér}

Az egyértelmüen előnyös fizikai tulajdonságok ellenére a gyakorlatban hasznosítható kapcsoló struktúrák megvalósítása a közelmúltig váratott magára, és létrejöttükhöz számos anyagtudományi, gyártástechnológiai kutatási eredményre volt szükség [7]. Egyes, kiváló tulajdonságokkal rendelkező anyagok esetében, mind például a gyémánt, a technológia fejlettsége még messze áll a gyakorlati alkalmazástól.

A teljesítmény kapcsolóeszközök tekintetében ma már tényként kezelhetjük a $\mathrm{SiC}$ és a GaN térhódítását, mindkét technológia megbízható eredményekkel szolgál, és sikerült megoldani olyan kérdéseket, mint pél- 
dául a kristályhibák sürüségének a drasztikus csökkentése. Míg 3-4 évvel ezelőtt érdekes, kiélezett szakmai vita folyt a „bajnok" kilétéről, ma már letisztultabb a helyzet: elöreláthatóan úgy a $\mathrm{SiC}$, mint a $\mathrm{GaN}$ megtalálja a vezető pozícióját, de a félvezetőipar különböző területein.

A SiC és a GaN kapcsolóeszközök gyártásában az ionimplantációs és a diffúziós szennyezési eljárások nem voltak eredményesek, de az epitaxiális kristálynövesztés járható útnak bizonyult [3]. A nagyteljesítményü, magas hőmérsékletủ működés megvalósításához a homoepitaxiális kristálynövesztés jelenti a megoldást, mivel nem merülnek fel kristályszerkezeti, hőtágulási, elektromos és hővezetési problémák a szubsztrátum és az epitaxiális réteg közötti átmenetnél [4]. A nagy átméröjü szubsztrátumok előállítása szempontjából a SiC-4H jóval sikeresebb, mint a GaN. A GaN félvezetök gyártása a heteroepitaxiális kristálynövesztés irányába tolódott el $\mathrm{Si}$, vagy $\mathrm{SiC}$ szubsztrátumon, illesztő (puffer) rétegek alkalmazását téve szükségessé a szubsztrátum és az epitaxiális GaN réteg között. Az egyik jól alkalmazható illesztő anyag a szigetelő AlN, de ez lehetetlenné teszi a nagyteljesítményü félvezető eszközöknél bevált vertikális struktúra kialakítását.

A GaN a hővezető képesség tekintetében elmarad a SiC-hoz képest, viszont jobbak a rádiófrekvenciás müködés szempontjából fontos tulajdonságai (például az elektronok mobilitása duplája a SiC-4H-hoz képest).

Érthető tehát, hogy a $\mathrm{GaN}$ félvezető eszközök elsősorban a laterális struktúra, és a rádiófrekvenciás nagyteljesítményü alkalmazások irányába fejlődtek [4]. A GaN rádiófrekvenciás katonai alkalmazásokhoz olyan eszközök gyártásában nyert teret, mint a MESFET és a HEMT [2].

A nagyteljesítményü, magas müködési hőmérsékletủ, vertikális struktúrájú kapcsolóeszközök megvalósítására a SiC-4H és a
SiC-6H közül az előbbi terjedt el, mert esetében lényegesen nagyobb, és izotróp a töltéshordozók mobilitása [3].

Egy további kihívás az, hogy a félvezetők magas hőmérsékleten történő működtetéséhez új tokozási technológiák szükségesek [9].

\section{Si-MOSFET és SiC-MOSFET félhíd típusú teljesítmény modulok összehasonlítása}

Példaként hasonlítsunk össze két nagyteljesítményű félvezető kapcsoló modult. Mindkettő MOSFET tranzisztorokat, illetve ezekkel ellenpárhuzamos diódákat tartalmaz, félhíd kapcsolásban, feszültséginverterek megvalósításához.

Az 1. táblázat az APTM120A15FG jelzésủ, Microsemi gyártmányú szilícium modul, illetve a HT-3201-R jelzésü, APEI gyártmányú modul néhány fontosabb jellemzőjét foglalja össze [8], [9].

A SiC MOSFET tranzisztorok egyik szokatlan tulajdonsága a hagyományos $\mathrm{Si}$ tranzisztorokkal szemben az, hogy a rácsvezérlő feszültségek elóállítása nehézkesebb. Egyrészt, a bekapcsoláshoz $U_{G S}=+20 \mathrm{~V}$ alkalmazása ajánlott, mert alacsonyabb rácsfeszültségek esetén az $U_{D S}$ vezetési feszültségesés számottevően megnő. A Si tranzisztorok esetében ugyanez jóval alacsonyabb rácsfeszültségeknél jelentkezik, és a vezetési veszteségek gyakorlatilag változatlanok $U_{G S}=+8 \mathrm{~V}$ fölött.

Másrészt, a $\mathrm{SiC}$ tranzisztorok esetében a lezáráshoz alkalmazott rácsfeszültség jelenleg kb. $U_{G S}=-5 V$-nál korlátozott. A helyes rácsvezérlő feszültségek eloóllítása több fejtörést okoz, mint a Si tranzisztorok esetében, amelyekre már nagyon sok szabványos megoldás all rendelkezésre. A magasabb feszültségszint nagyobb rácstöltést, így nagyobb vezérlési teljesítményszükségletet is jelent, bár a két vizsgált modul rácskapacitása hasonló (1. táblázat). 
1. táblázat. Az összehasonlitás alapjául szolgáló tranzisztorparaméterek Si-MOSFET és SiCMOSFET félíd típusú modulok esetében

\begin{tabular}{|l|l|l|l|}
\hline Teljesítmény modul & & APTM120A15FG & HT-3201-R \\
\hline Félvezetö anyag & & $\mathrm{Si}$ & $\mathrm{SiC}$ \\
\hline Maximális D-S feszültség & $\mathrm{U}_{\mathrm{DSS}}$ & $1200 \mathrm{~V}$ & $1200 \mathrm{~V}$ \\
\hline $\begin{array}{l}\text { Vezetési Drain-Source } \\
\text { ellenállás }\end{array}$ & $\begin{array}{l}\mathrm{R}_{\mathrm{DSon}} @ 25^{\circ} \mathrm{C}, \mathrm{U}_{\mathrm{GS}}=20 \mathrm{~V}, \\
\mathrm{I}_{\mathrm{D}}=180 \mathrm{~A}\end{array}$ & $175 \mathrm{~m} \Omega$ & $3.6 \mathrm{~m} \Omega$ \\
\hline Bemeneti kapacitás & $\mathrm{C}_{\text {iss }} @ \mathrm{U}_{\mathrm{GS}} 0 \mathrm{~V}$ & $20.6 \mathrm{nF}$ & $19.5 \mathrm{nF}$ \\
\hline Össz rácstöltés & $\mathrm{Q}_{\mathrm{g}}$ & $748 \mathrm{nC} @ \mathrm{U}_{\mathrm{GS}} 10 \mathrm{~V}$ & $\begin{array}{l}1127 \mathrm{nC} @ \\
\mathrm{U}_{\mathrm{GS}} 20 \mathrm{~V}\end{array}$ \\
\hline Kikapcsolási veszteség & $\begin{array}{l}\mathrm{E}_{\text {off }} @ \mathrm{U}_{\mathrm{DS}}=800 \mathrm{~V}, \\
\mathrm{I}_{\mathrm{D}}=120 \mathrm{~A}, \mathrm{~T}_{\mathrm{j}}=125^{\circ} \mathrm{C}, \\
\mathrm{R}_{\mathrm{G}}=1.2 \Omega\end{array}$ & $7 \mathrm{~mJ}$ & $1.7 \mathrm{~mJ}$ \\
\hline $\begin{array}{l}\text { Bekapcsolási veszteség } \\
{ }^{*}\end{array}$ & $\begin{array}{l}\mathrm{E}_{\mathrm{o}} @ \mathrm{U}_{\mathrm{DS}}=800 \mathrm{~V}, \\
\mathrm{I}_{\mathrm{D}}=120 \mathrm{~A}, \mathrm{~T}_{\mathrm{j}}=125^{\circ} \mathrm{C}, \\
\mathrm{R}_{\mathrm{G}}=1.2 \Omega\end{array}$ & $11 \mathrm{~mJ}$ & $0.77 \mathrm{~mJ}$ \\
\hline $\begin{array}{l}\text { A félvezetö struktúra ma- } \\
\text { ximális hömérséklete }\end{array}$ & $\theta_{\mathrm{Jmax}}$ & $150^{\circ} \mathrm{C}$ & $225^{\circ} \mathrm{C}$ \\
\hline $\begin{array}{l}\text { A tranzisztor félvezető } \\
\text { struktúrája és a tokozás } \\
\text { közti termikus ellenállás }\end{array}$ & $\mathrm{R}_{\text {thJC }}$ & $0.1^{\circ} \mathrm{C} / \mathrm{W}$ & $0.1^{\circ} \mathrm{C} / \mathrm{W}$ \\
\hline Alapterület & $\mathrm{S}$ & & $110 \mathrm{x} 65$ \\
\hline
\end{tabular}

"A táblázatban feltüntetett kapcsolási veszteségek az összehasonlítás céljából végzett közelítő számítások eredményei.

\subsection{A hőleadás feltételei}

A SiC hővezető képessége háromszor jobb, mint a szilíciumé, ugyanakkor, a magas müködési hömérséklet nagy mértékben megkönnyíti a hőleadást.

A tokozás és a hütővíz közötti termikus ellenállás mindkét modul esetében hozzávetőlegesen:

$$
R_{t h C H}+R_{t h H A}=0.134^{\circ} \mathrm{C} / \mathrm{W}
$$

A tranzisztor félvezető struktúrája és a tokozás közti termikus ellenállás a két modul esetében megegyezik.

Vizsgáljuk meg, hogy mekkora maximális teljesítmény disszipálható az egyes modulok tranzisztorain anélkül, hogy azok átlagos $\theta_{J}$ hömérséklete meghaladná a megengedett határt.

Az egyszerüség kedvéért ne vegyük figyelembe a diódák veszteségeit, amelyek befolyásolják a tokozás hőmérsékletét. Adott méretezési feladat esetén a diódák termikus igénybevétele az áramirányító müködési feltételeiből határozható meg. $\theta_{a \max }=40{ }^{\circ} \mathrm{C}$ maximális hủtővíz hőmérsékletet feltételezve, $\Delta \theta=25{ }^{\circ} \mathrm{C}$ biztonsági tartalékkal, a tranzisztorok maximálisan megengedhető disszipált teljesítménye a (2) összefüggéssel számítható.

$$
P_{\max }=\frac{\theta_{J \max }-\theta_{a \max }-\Delta \theta}{R_{t h J C}+R_{t h C H}+R_{t h H A}}
$$

$\mathrm{Az}$ 1. táblázat adatainak a figyelembe vételével $\quad P_{\text {max } \_S i}=363 \mathrm{~W}, \quad$ illetve $P_{\text {max } \_S i C}=683 \mathrm{~W}$.

\subsection{A kapcsolási veszteségek összeha- sonlítása}

Vizsgáljuk meg, hogy hasonló üzemi feltételek esetén mekkora a két félvezető eszközön létrejövő kapcsolási veszteségek közti eltérés. Hiteles gyakorlati mérés nehe- 
zen kivitelezhető, mert a modulok külső áramkörhöz való csatlakozási módja eltérö, így az áramköri paraméterek azonossága nem garantálható. Különböző gyártók kapcsolóeszközeinek az összehasonlítása katalógusadatok alapján nem egyszerü feladat, mert a feltüntetett paraméterek értelmezési módja, illetve a meghatározásukhoz használt mérési körülmények nem egységesek. Általában a mérést úgynevezett hardswitching üzemmódban végzik, amely sokkal könnyebben átlátható, mit a soft (kímélő) kapcsolási üzemmódok áramköri folyamatai. Az ipari alkalmazások túlnyomó részében hard-switching üzemmódban müködő áramirányítókat használnak. A félvezető kapcsolóeszközök piacát is sok esetben ezeknek a konvertereknek a szempontjából kell szemlélni, így érthetővé válik az a tény is, hogy az adatlapok keveset, vagy egyáltalán nem foglalkoznak a kímélő kapcsolási üzemmódok jellemzésével.

Összehasonlítás céljából a két adatlapban található, eltérő mérési feltételekből származó adatokat a jelleggörbék linearizálásával és interpolációval azonos feltételekre számítjuk át (nemlineáris interpolációval pontosabb közelítés kapható [7]). Mivel a két eszköz rácskapacitása közel áll egymáshoz, célszerünek látszik azonos rácsellenállások használata, legalábbis a kapcsolási késleltetések szempontjából. A hard-switching üzemmód veszteségeinek számításánál egy szokásos közelítés azokat a tranzisztor lezárt állapotához tartozó $\mathrm{U}_{\mathrm{DS}}$ feszültséggel arányosnak tekinteni.

Az APTM120A15FG tranzisztor jelleggörbéiből lineáris közelítéssel, $U_{D S}=800 \mathrm{~V}$ és $\theta_{J}=125^{\circ} \mathrm{C}$ esetén:

$$
\begin{aligned}
& \frac{\partial E_{o n}}{\partial R_{G}}=0.48 \frac{m J}{\Omega} ; \quad \frac{\partial E_{o f f}}{\partial R_{G}}=1.4 \frac{m J}{\Omega} ; \\
& \frac{\partial E_{o n}}{\partial I_{D}}=0.0766 \frac{m J}{A} ; \quad \frac{\partial E_{o f f}}{\partial I_{D}}=0.0587 \frac{m J}{A}
\end{aligned}
$$

A HT-3201-R modul esetében a dokumentáció készítése kezdetlegesebb stádiumban van, de tudni lehet, hogy a modul 7 db. CPM2-1200-0025 típusú tranzisztor chip-et és $6 \mathrm{db}$. CPW5-1200-Z050 típusú dióda chip-et tartalmaz [10], [11]. A CPM21200-0025 katalóguslapjában nem találunk a kapcsolási veszteségekre vonatkozó jelleggörbéket, de ugyanezt a chip-et használja a C2M-0025-120D típusú tranzisztor, amelynek már kiforrottabb adatlapja van, veszteség-karakterisztikákkal, ahonnan:

$$
\begin{aligned}
& \frac{\partial E_{\text {on }}}{\partial R_{G}}=0.053 \frac{\mathrm{mJ}}{\Omega} ; \frac{\partial E_{\text {off }}}{\partial R_{G}}=0.066 \frac{\mathrm{mJ}}{\Omega} ; \\
& \frac{\partial E_{\text {on }}}{\partial I_{D}}=0.04 \frac{\mathrm{mJ}}{\mathrm{A}} ; \frac{\partial E_{\text {off }}}{\partial I_{D}}=0.02 \frac{\mathrm{mJ}}{\mathrm{A}} \\
& \frac{\partial E_{\text {on }}}{\partial \theta}=-0.002 \frac{\mathrm{mJ}}{{ }^{\circ} \mathrm{C}} ; \frac{\partial E_{\text {off }}}{\partial \theta}=0.00125 \frac{\mathrm{mJ}}{{ }^{\circ} \mathrm{C}}
\end{aligned}
$$

A CPM2-1200-0025 tranzisztor jelleggörbéiből kiolvasható, hogy

$R_{G_{-} \text {ext }}=6.8 \Omega ; I_{D}=50 \mathrm{~A}$;

$U_{D S}=800 \mathrm{~V} ; \theta_{J}=25^{\circ} \mathrm{C}$

esetén

$$
E_{\text {on }}=1.6 \mathrm{~mJ} ; E_{\text {off }}=0.75 \mathrm{~mJ} .
$$

Ezen értékek környezetében végezzük a kapcsolási veszteségek közelítő számítását sorbafejtéssel.

A fenti megfontolásokkal, figyelembe véve a CPM2-1200-0025 tranzisztor $1.2 \Omega-o s$ belső rácsellenállását, a HT3201-R modul kapcsolási veszteségei az APTM120A15FG karakterisztikáin még azonosítható $I_{D}=120 \mathrm{~A}$ áramerősségre, $\theta_{J}=125^{\circ} \mathrm{C}$ hömérsékletre és $R_{G}=1.2 \Omega$ rácsellenállásra:

$$
E_{\text {on }}=0.77 \mathrm{~mJ} ; E_{\text {off }}=1.71 \mathrm{~mJ} .
$$




\subsection{A vezetési veszteségek összeha- sonlítása}

Névleges rácsfeszültség mellett a két eszközt ugyanazzal a konstans árammal terhelve, hasonlítsuk össze a vezetési veszteségeket a fent tárgyalt hütési feltételek mellett.

A probléma megoldása iteratív módon lehetséges, mert a félvezető hőmérséklete jelentősen befolyásolja a vezetési ellenállást, és így a vezetési veszteséget. Az $R_{D S o n}$ ellenállás úgy a hőmérséklettel, mint a drain áram erősségével növekszik, és az adott körülményeknek megfelelö ellenállás megközelítően a (7) összefüggéssel számítható.

$$
\begin{aligned}
& R_{D S}\left(I_{D}, \theta\right)=R_{D S}\left(I_{D 0}, \theta_{0}\right)^{*} \\
& *\left(1+\frac{\partial R_{D S}^{*}}{\partial I_{D}}\left(I_{D}-I_{D 0}\right)+\frac{\partial R_{D S}^{*}}{\partial \theta}\left(\theta-\theta_{0}\right)\right)
\end{aligned}
$$

ahol $R_{D S}^{*}$ az $R_{D S}$ ellenállásnak az adatlapban szereplö, $R_{D S}\left(I_{D 0}, \theta_{0}\right)$-hoz viszonyított értéke.

Legyen például a szilícium tranzisztor esetén $I_{D}=40 \mathrm{~A}, U_{G S}=+10 \mathrm{~V}$. Így, az első lépésben, $\theta_{J}=100^{\circ} \mathrm{C}$ hőmérsékletre $R_{D S}=266 \mathrm{~m} \Omega$ adódik.
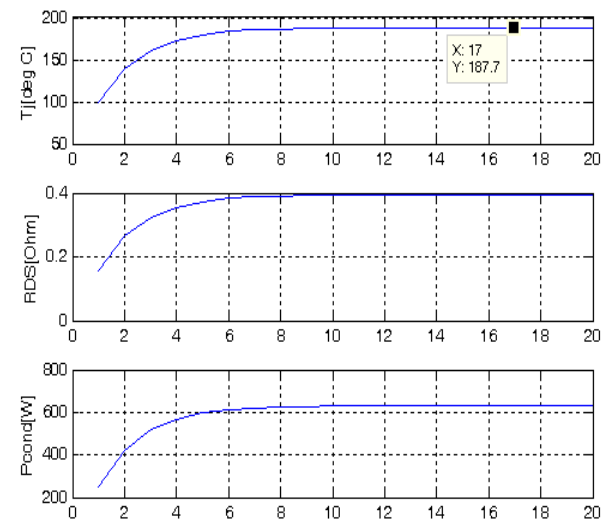

2. ábra. A tranzisztorhömérséklet, a hömérsékletfüggö ellenállás és a disszipált teljesitmény iterativ számitásának eredménye
Ezzel az ellenállásértékkel a vezetési veszteség $P_{\text {cond }}=426 \mathrm{~W}$. Újabb iterációk során a számítás eredménye $\theta_{J}=188^{\circ} \mathrm{C}$ körül stabilizálódik, ami messze meghaladja a megengedett határt (2. ábra).

A 3. ábrán megfigyelhető, hogy $\mathrm{kb} .55 A$-es áramerösség fölött már nem is jön létre stabil müködési állapot, és a hőmérséklet korlátlanul növekszik, elsősorban az ellenállás pozitív hőmérsékleti együtthatójának köszönhető pozitív visszacsatolás miatt. Megjegyzendő, hogy a hőmegfutási jelenség a tranzisztor hőmérsékletétől független drain áram feltételezésével jött létre.

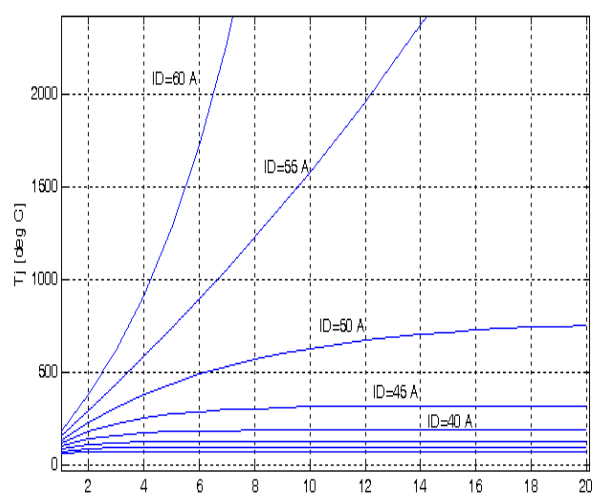

\section{3. ábra. Az APTM120A15FG Si MOSFET tran- zisztor hömérséklete különbözö drain áramok esetén}

Az áramirányítók esetében ez így is van, hiszen a tranzisztor vezetési állapotában az áram erősségét a külső áramkör határozza meg. A 4. ábrán megfigyelhető, hogy mennyire érzékennyé válhat a hőmérséklet az áramerösség kis változásaira. Például, $I_{D}$ növelése $35 A$-ról $38 A$-re (vagyis csupán $8.5 \%$-kal), a félvezető struktúra hőmérsékletét a még elfogadható $126.5^{\circ} \mathrm{C}$ ról ( $23.5^{\circ} \mathrm{C}$ tartalék) a már megengedhetetlen $159^{\circ} \mathrm{C}$-ra emeli. Jogosan tevődik fel tehát a kérdés, hogy mennyiben szabad a $\mathrm{Si}$ MOSFET tranzisztort ilyen magas hőmér- 
sékleten müködtetni, illetve az, hogy menynyiben bízható a tranzisztor ,sorsa" a túláram védelemre. Most már az is sejthető, hogy miért definiálták a tranzisztor gyártói vonatkoztatási alapként az $I_{D}=30 \mathrm{~A}$-es áramerősséget. A HT-3201-R $\mathrm{SiC}$ modul MOSFET tranzisztorainak esetében, a felépítésében szereplő CPM2-1200-0025B tranzisztor chipek katalógusadatai alapján,

$$
R_{D S}\left(I_{D 0}, \theta_{0}\right)=3.6 m \Omega
$$

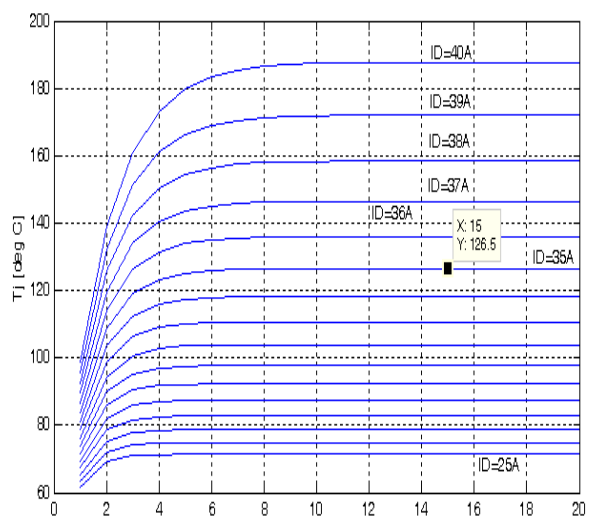

4. ábra. Az APTM120A15FG Si MOSFET tranzisztor hömérsékletének érzékeny változása a drain áram függvényében

$$
\frac{\partial R_{D S}^{*}}{\partial I_{D}}=6.4 e-3, \quad \frac{\partial R_{D S}^{*}}{\partial \theta}=5.3 e-3
$$

Viszonylag durva közelítéssel a $(200 A \ldots 500 A)$ drain áramerősség tartományra érvényes következtetések is levonhatók (7) felhasználásával.

Az APTM120A15FG Si tranzisztoréval azonos hütési feltételek mellett a félvezetö struktúra hőmérséklete az 5. ábrán látható módon alakul a drain áram erősségének függvényében. Megfigyelhető, hogy $I_{D}=300 A$-nél a félvezető struktúra hömérséklete $150^{\circ} \mathrm{C}$, vagyis messze a megengedett $225^{\circ} \mathrm{C}$ alatti. Ez egy nagyságrenddel nagyobb drain áramot jelent, mint amit az ugyanakkora méretủ SiMOS modullal el tudunk érni.

A 6. ábrán megfigyelhető, hogy itt kb. $475 \mathrm{~A}$-nél lép fel ugyanolyan hőmegfutás típusú instabilitás, mint amilyent a Si MOS esetében $\mathrm{kb} .55 A$-nél tapasztaltunk.

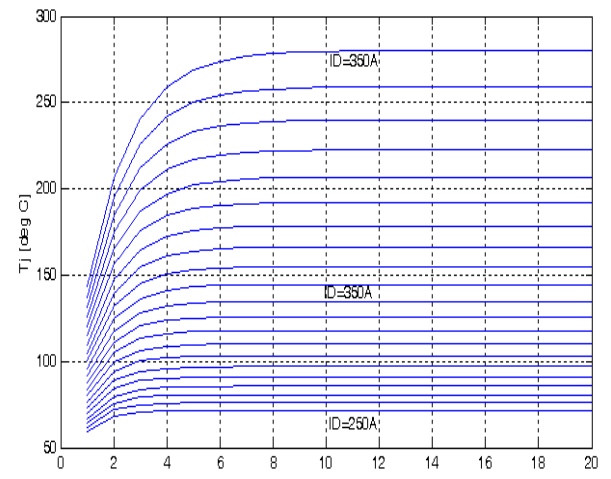

5. ábra. A HT-3201-R SiC MOSFET tranzisztor hömérsékletének változása a drain áram függvényében

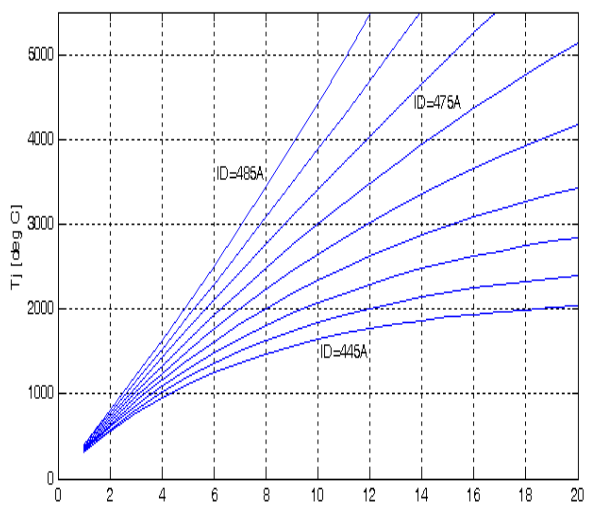

6. ábra. A 3201-R SiC modul MOSFET tranzisztorainak a hömegfutása

\section{Következtetések}

A széles tiltott sávú félvezető kapcsolóeszközök alkalmazása várhatóan úgy a nagyteljesítményü, mint a nagyfekvenciás áramirányítók terén a közeljövő uralkodó irányzata lesz. A már kereskedelemben is kapható SiC-MOSFET nagyteljesítményü 
kapcsolóeszközök alkalmazása révén az áramirányítók teljesítménysürüségének és hatásfokának a számottevő növekedése érhető el, és a magas működési hőmérséklet a hütési feladatok hatékony megoldását teszi lehetővé.

\section{Szakirodalmi hivatkozások}

[1] Biela, J., Schweizer, M., Waffler, S., Kolar, J. W.: SiC versus Si-Evaluation of Potentials for Performance Improvement of Inverter and DC-DC Converter Systems by $\mathrm{SiC}$ Power Semiconductors. IEEE Trans. on Industrial Electronics, Vol. 58, No. 7, Jul. 2011, pp. 2872-2882.

[2] Javorka, P.: Fabrication and Characterization of AlGaN/GaN High Electron Mobility Transistors- Ph. D. Thesis, Aachen, 2004, p.7.

[3] Wijesundara, M., Azevedo, R.: Silicon Carbide Microsystems for Harsh Environments, Ch. 2: SiC Materials and Processing Technology. Springer, 2011, pp. 33-84.

[4] Microsemi: Gallium Nitride (GaN) versus Silicon Carbide (SiC) in the High Frequency $(R F)$ and Power Switching Applications. Report, pp. 1-8,
https://www.digikey.com/Web\%20Export/S upplier\%20Content/Microsemi_278/PDF/Mi crosemi GalliumNitride VS SiliconCarbide. pdf?redirected $=1$.

[5] Peftitsis, D.: On Gate Drivers and Applications of Normally-ON SiC JFETs., Doctoral Thesis, Stockholm, 2013.

[6] Clarke, R. C., és mások: SiC Static Induction Transistors. Final Report, Office of Naval Research, Westinghouse STC, 1995.

[7] Ozpineci, B., Tolbert, L. M.: Comparison of Wide-Bandgap Semiconductors for Power Electronics Applications. Report, Oak Ridge National Laboratory, U. S. Department of Energy, http://www.osti.gov/bridge, 2013, p.16.

[8] Microsemi Power Products Group: APTM120A15FG, Data Sheet- Rev. 2, 2012.

[9] APEI: HT-3201-R, High Temperature SiC Half-Bridge Power Module- Preliminary, Rev. 1.6, 2015, pp. 1-15.

[10] CREE: CPW5-1200-Z050B Silicon Carbide Schottky Diode Chip, Z-RecTM Rectifier, 2013, pp. 1-4.

[11] CREE: CPM2-1200-0025B Silicon Carbide Power MOSFET C2MTM MOSFET Technology, 2014, pp. 1-7. 